\title{
Permeabilidad y estructura porosa de hormigones autocompactantes de resistencia moderada
}

\section{Permeability and pore size distribution in medium strength self-compacting concrete}

\author{
E. B. Bermejo(*), A. Moragues(*), J. C. Gálvez ${ }^{(*)}$, M. Fernández Cánovas(*)
}

Recepción/Received: 16-II-2009

Aceptación/Accepted: 13-III-2009

Publicado online/Online publishing: 11-VIII-2010

\section{RESUMEN}

El hormigón autocompactante ha experimentado un amplio desarrollo en los últimos años. Los estudios sobre este hormigón se han centrado en obtener dosificaciones óptimas, mientras los relativos a su durabilidad son escasos, especialmente en el caso de hormigones de resistencia moderada.

Este trabajo se centra en el estudio de la permeabilidad de distintos hormigones autocompactantes de resistencia moderada (resistencia característica $30 \mathrm{MPa}$ ). El estudio incluye hormigones fabricados con cementos comunes, en los que se ha buscado un equilibrio entre prestaciones y precio. Con el fin de estudiar su comportamiento frente a la penetración de agentes agresivos, se han realizado los ensayos de permeabilidad al agua bajo presión y estudio de la porosimetría por intrusión de mercurio.

Los resultados de los ensayos ponen de manifiesto el buen comportamiento de estos hormigones frente a la posible penetración de agentes agresivos por la red capilar.

Palabras clave: hormigón autocompactante, durabilidad, microestructura, permeabilidad, porosimetría.
SUMMARY

The use of self-compacting concrete (SCC) has been on the rise in recent years. Research on this type of concrete has focused primarily on determining optimal dosage, while durability, particularly for medium strength SCC, has received much less attention.

The present study explored the permeability of a number of medium strength (characteristic strength, $30 \mathrm{MPa}$ ) self-compacting concretes, including SCCs made with common cement, in pursuit of a balance between performance and cost. Pressurised water and mercury intrusion porosimetry tests were conducted to determine concrete behaviour when exposed to aggressive agents.

The findings showed that the capillary networks of these concretes are essentially impermeable to aggressive agents.

Keywords: self-compacting concrete, durability, microstructure, permeability, porosimetry.

(*) Universidad Politécnica de Madrid (Madrid, España). 


\section{INTRODUCCIÓN}

Los primeros trabajos desarrollados con hormigón autocompactante (HAC) se llevaron a cabo en Japón, a mitad de los años 80, bajo la dirección del profesor Okamura (1). Desde entonces se ha avanzado mucho en el conocimiento de este hormigón, sobre todo en el ámbito de las altas prestaciones. A medida que se extiende y generaliza el uso del HAC empiezan a fabricarse HACs de resistencias moderadas y medias. Se han dedicado importantes esfuerzos en la optimización de la dosificación y el estudio de las propiedades en estado fresco (26 ), sin embargo aún hay muchos aspectos pendientes de estudio en el campo de la durabilidad, especialmente de HACs de resistencia moderada (7-8).

Dentro del amplio campo de la durabilidad, este trabajo se centra en los aspectos relacionados con el transporte de compuestos agresivos a través de la red porosa del hormigón. Trabajos previos (7, 9-11) han puesto de manifiesto que el alto contenido de finos y el empleo de dosis mayores de superplastificantes, en comparación con el hormigón convencional (HC), modifican la estructura porosa, afectando a los mecanismos de transporte de líquidos y gases en el hormigón.

La Unión Internacional de Química Pura y Aplicada (IUPAC) clasifica los poros por su tamaño en: microporos $(\phi<2 \mathrm{~nm})$, meso-poros (2 nm $<\phi<50 \mathrm{~nm})$ y macro-poros ( $\phi>50 \mathrm{~nm}$ ). De todos ellos, son los mesoporos los que determinan en mayor medida el comportamiento permeable del hormigón por su mayor conexión $(4,12)$.

El presente trabajo tiene como objetivo estudiar la permeabilidad y la estructura porosa de HACs de resistencia moderada, confeccionados con los cementos habitualmente empleados en la fabricación de HC. Dado que tanto el comportamiento en estado fresco como la estructura porosa del HAC son dependientes de la combinación cemento-aditivo-filler, se han obtenido las dosificaciones de HAC para los cementos más habituales, de acuerdo a la vigente Instrucción para la Recepción de Cementos (RC-08) (13). La investigación se centra en los hormigones de resistencia característica a compresión de $30 \mathrm{MPa}$, de modo que pequeñas modificaciones permitan conseguir HAC con resistencia característica comprendida entre 25 y $35 \mathrm{MPa}$, habitual en edificación.

Uno de los aspectos clave del HAC de resistencia moderada es su precio en relación al $\mathrm{HC}$, de modo que sea económicamente rentable. Con este fin se han buscado dosificaciones que no superasen los $350 \mathrm{~kg}$ de cemento por metro cúbico de hormigón y que empleasen contenidos bajos de aditivos.

\section{INTRODUCTION}

The earliest studies on self-compacting concrete (SCC) were conducted in the mid nineteen eighties by Professor Okamura in Japan (1). Much has been learnt about this type of concrete in the interim, in particular in the high-strength range. As the use of SCC has become more widespread, however, manufacturers have begun to make medium strength classes. While substantial effort has been devoted to optimizing dosage and the study of fresh concrete properties (2-6), many aspects of durability have yet to be explored, particularly in medium-strength SCCS (7-8).

One such aspect, addressed in the present study, is: the transport of aggressive compounds across the concrete pore network. According to the literature (7, 9-11), a higher fines content and larger doses of superplasticizers than used in conventional concrete (CC) modify pore structure, affecting liquid and gas transport mechanisms in concrete.

The International Union for Pure and Applied Chemistry (IUPAC) classifies pores by sizes as follows: micro-pores $(\phi<2 \mathrm{~nm})$, meso-pores (2 nm $<\phi<50 \mathrm{~nm})$ and macropores $(\phi>50 \mathrm{~nm})$. Of the three, meso-pores play the predominant role in concrete permeability, due to their greater connectivity $(4,12)$.

The present study aimed to explore permeability and pore structure in medium strength SCCS made with cement normally used to prepare conventional concrete. Since both the fresh state and pore structure of SCC depend on the cement-admixture-filler combination, SCC was proportioned with the two most common types of cement as specified in the existing Spanish Cement Acceptance Code (RC-08) (13). The research focused on concretes with a characteristic compressive strength of $30 \mathrm{MPa}$ so that minor changes yielded SCCS with characteristic strength values ranging from the 25 to 35 MPa normally used in buildings.

One of the key issues of medium strength SCC is its costeffectiveness in relation to $C C$. In light of this consideration, the concretes studied were proportioned to use no more than $350 \mathrm{~kg}$ cement per cubic metre of concrete and small percentages of admixture. 


\section{CAMPAÑA EXPERIMENTAL}

\subsection{Componentes de los hormigones}

\section{Cementos}

Dado que no hay requisitos específicos en cuanto al tipo de cemento a emplear en la confección de un HAC, se han empleado aquellos que cumplen con la vigente Instrucción para la Recepción de Cementos (RC-08) (13).

Los cementos empleados en el estudio han sido los siguientes:

- EN 197-1 CEM I 42,5 R;

- EN 197-1 CEM II/A-V 42,5 N;

- EN 197-1 CEM II/A-S 42,5 N;

- EN 197-1 CEM II/A-P 42,5 R;

- EN 197-1 CEM II/A-V 42,5 R;

- EN 197-1 CEM II/B-L 32,5 N;

- Cemento blanco: BL II/A-L 42,5 R;

- Cemento con característica adicional de resistencia a los sulfatos: I 42,5 R/SR.

\section{Áridos}

Se ha empleado arena de río (0-4 $\mathrm{mm}$ ) y árido grueso rodado (4-16 $\mathrm{mm})$, ambos de naturaleza silícea. El tamaño máximo del árido ha sido de $16 \mathrm{~mm}$, siendo el módulo granulométrico de la arena de 3,70.

\section{Adiciones}

Se han empleado dos tipos de adiciones:

- Filler calizo. Utilizado con todos los tipos de cementos. Es un material que procede de moler el árido calizo y la mayor parte del material pasa por el tamiz 0,063 mm. Su granulometría cumple con la norma UNE 12620:2002.

- Ceniza volante, procedente de la Central Térmica de Andorra (Teruel). Se ha empleado únicamente con el cemento sulforesistente (I 42,5 R/SR). Es de naturaleza silícea y de bajo contenido en óxido de calcio, clasificada como tipo $\mathrm{V}$ de acuerdo a RC-08 (13), cumpliendo con las normas UNE EN 450-1:2006 y UNE EN 450-2:2006.

La cantidad máxima de partículas finas añadidas o filler (que pasan por el tamiz UNE 0,063 mm), incluidas las adicionadas al cemento, no superó los $250 \mathrm{~kg}$ por metro cúbico de hormigón.

\section{Aditivo}

En todos los hormigones fabricados se ha empleado el mismo aditivo superplastificante, SIKA Viscocrete 3425,

\section{EXPERIMENTAL}

\subsection{Concrete components}

\section{Cements}

In the absence of any specific requirements on the type of cement to be used in SCC, only cements compliant with the existing Spanish Cement Acceptance Code (RC08) (13) were chosen for use in the present study.

These included:

- $\quad$ EN 197-1 CEM I 42.5 R;

- EN 197-1 CEM II/A-V $42.5 \mathrm{~N}$;

- EN 197-1 CEM II/A-S $42.5 \mathrm{~N}$;

- EN 197-1 CEM II/A-P 42.5 R;

- EN 197-1 CEM II/A-V 42.5 R;

- $E N$ 197-1 CEM II/B-L $32.5 \mathrm{~N}$;

- White cement: BL II/A-L 42.5 R;

- Sulphate resistant cement I 42.5 R/SR.

\section{Aggregates}

Siliceous rolled sand $(0-4 \mathrm{~mm})$ and smooth coarse aggregate (4-16 $\mathrm{mm})$, also siliceous, were used to prepare the concretes. The maximum aggregate size was $16 \mathrm{~mm}$, while the fineness modulus of the sand was 3.70.

\section{Additions}

Two types of additions were used:

- $\quad$ Limestone filler. Used with all the cement types. Most of the material used, obtained by grinding limestone, passed through a 0.063- $\mathrm{mm}$ sieve. Its particle size distribution was Spanish standard UNE 12620:2002-compliant.

- Fly ash from the Andorra steam power plant in the Spanish province of Teruel. This siliceous addition with a low calcium oxide content, classified as type $V$ in Spanish code RC-08 (13) and compliant with Spanish and European standards UNE EN 450-1:2006 and UNE EN 450-2:2006, was used with the sulphate-resistant cement only (I $42.5 \mathrm{R} / \mathrm{SR}$ ).

The total amount of fine particles or filler added (passing a standard $0.063 \mathrm{~mm}$ sieve), including the amounts added to the cement, was $250 \mathrm{~kg}$ per cubic metre of concrete or under.

\section{Admixture}

All the concrete was prepared with the same superplasticizer, SIKA Viscocrete 3425, a water-based 
basado en policarboxilatos modificados en base acuosa. No se han empleado aditivos modificadores de viscosidad.

\subsection{Fabricación de las probetas}

A partir de las recomendaciones disponibles (2, 5-6, 1416) se han diseñado las dosificaciones de HAC para obtener una resistencia característica de $30 \mathrm{MPa}$. En la Tabla 1 se muestran las dosificaciones empleadas para cada uno de los hormigones estudiados. Las mismas han permitido obtener, en general, hormigones de resistencia característica superior a $30 \mathrm{MPa}$ que cumplen con los requisitos de $\mathrm{HAC}$ en estado fresco. modified polycarboxylate compound. Admixtures that modify viscosity were not used.

\subsection{Specimen preparation}

The SCCS were batched to obtain a characteristic strength of $30 \mathrm{MPa}$, using the recommendations available $(2,5-6,14-16)$ as a guideline. Table 1 gives the proportions used in each of the concretes studied. Most of the concretes obtained had a characteristic strength of over $30 \mathrm{MPa}$ and met fresh state requirements for SCC.

Tabla 1 / Table 1

Dosificaciones propuestas para cada hormigón estudiado por $\mathrm{m}^{3}$ de hormigón. Concrete proportioning per $\mathrm{m}^{3}$.

\begin{tabular}{|c|c|c|c|c|c|c|c|c|c|}
\hline Hormigón / Concrete & 1 & 2 & 3 & 4 & 5 & 6 & 7 & 8 & 9 \\
\hline $\begin{array}{l}\text { Tipo de cemento / } \\
\text { Cement type }\end{array}$ & I $42.5 \mathrm{R} / \mathrm{SR}$ & $\begin{array}{c}\text { CEM II/A-V } \\
42.5 \mathrm{~N}\end{array}$ & $\begin{array}{c}\text { CEM II/A-V } \\
42.5 \mathrm{R}\end{array}$ & CEM I $42.5 \mathrm{R}$ & I $42.5 \mathrm{R} / \mathrm{SR}$ & $\begin{array}{c}\text { CEM II/A-S } \\
42.5 \mathrm{~N}\end{array}$ & $\begin{array}{c}\text { BL II/ } \\
\text { A-L 42.5 R }\end{array}$ & $\begin{array}{l}\text { CEM II/A-P } \\
42.5 \mathrm{R}\end{array}$ & $\begin{array}{c}\text { CEM II/B-L } \\
32.5 \mathrm{~N}\end{array}$ \\
\hline Adición / Addition & $\begin{array}{c}\text { Ceniza volante / } \\
\text { Fly ash }\end{array}$ & \multicolumn{8}{|c|}{ Filler calizo / Limestone filler } \\
\hline $\begin{array}{c}\text { Cemento / Cement } \\
(\mathrm{kg})\end{array}$ & 280 & 300 & 325 & 350 & 325 & 350 & 375 & 350 & 350 \\
\hline $\begin{array}{c}\text { Adición / Addition } \\
(\mathrm{kg})\end{array}$ & 200 & 200 & 200 & 200 & 220 & 200 & 156 & 200 & 110 \\
\hline Agua $\left({ }^{*}\right) /$ Water $(\mathrm{kg})$ & 140 & 150 & 162 & 193 & 179 & 193 & 206 & 193 & 193 \\
\hline Arena / Sand (kg) & 960 & 960 & 960 & 960 & 960 & 960 & 960 & 960 & 960 \\
\hline Grava / Gravel (kg) & 695 & 695 & 695 & 695 & 695 & 695 & 695 & 695 & 695 \\
\hline $\begin{array}{c}\text { Aditivo I } \\
\text { Superplasticizer (kg) }\end{array}$ & $\begin{array}{c}4.62 \\
(1.65 \%)\end{array}$ & $\begin{array}{c}3.90 \\
(1.30 \%)\end{array}$ & $\begin{array}{l}6.50 \\
(2 \%)\end{array}$ & $\begin{array}{c}7.35 \\
(2.10 \%)\end{array}$ & $\begin{array}{c}7.05 \\
(2.17 \%)\end{array}$ & $\begin{array}{c}2.80 \\
(0.80 \%)\end{array}$ & $\begin{array}{c}4.31 \\
(1.15 \%)\end{array}$ & $\begin{array}{c}6.34 \\
(1.81 \%)\end{array}$ & $\begin{array}{c}6.65 \\
(1.90 \%)\end{array}$ \\
\hline$a / c / w / c$ & 0.50 & 0.50 & 0.50 & 0.55 & 0.55 & 0.55 & 0.55 & 0.55 & 0.55 \\
\hline
\end{tabular}

$\left(^{*}\right)$ Esta cifra corresponde al agua total, incluida la humedad de los áridos y la que aporta el aditivo. / (*) This figure refers to total water, including aggregate moisture and water included in the admixture.

Una vez adoptada la dosificación idónea para cada cemento utilizado se confeccionaron dos amasadas para cada dosificación, fabricándose probetas cilíndricas de 15 $\phi \times 30 \mathrm{~cm}$ de altura para la realización de ensayos a compresión, módulo de elasticidad, tracción indirecta, penetración de agua bajo presión y ensayo de porosimetría por intrusión de mercurio.

\subsection{Ensayos sobre hormigón fresco}

Los ensayos realizados fueron tres: extensión de flujo (UNE 83361:2007), caja en L (UNE 83363:2007) y embudo V (UNE 83364:2007), siempre en el mismo orden. El primer ensayo fue el de extensión de flujo, cuyo objetivo era evaluar la capacidad de fluir del hormigón y, además, comprobar visualmente la posible segregación del mismo. El siguiente fue el de la caja en $L$, cuyo objetivo era cuantificar el posible bloqueo de la masa fresca al pasar entre armaduras, así como la fluidez del hormigón. Por último, se realizó el ensayo del embudo en V, cuyo
Two batches of each concrete were prepared and cylindrical specimens (15 $\phi \times 30 \mathrm{~cm}$ ) moulded to conduct the compressive strength, Young's modulus of elasticity, splitting tensile strength, penetration depth of water under pressure and mercury intrusion porosimetry tests.

\subsection{Fresh concrete}

Three tests were conducted: slump flow (UNE 83361:2007), L-box (UNE 83363:2007) and V-funnel (UNE 83364:2007), always in the same order. The first trial conducted was the slump test, to evaluate concrete flowability and visually check the material for possible segregation. Secondly, concrete was tested in the L-box to quantify the possible blockage of the flow of the fresh concrete around the reinforcement, as well as flowability. The purpose of the $V$-funnel test, conducted last, was to evaluate 
objetivo era evaluar la capacidad del hormigón para fluir por zonas de paso estrechas y la capacidad de relleno de los moldes.

\subsection{Ensayos sobre hormigón endurecido}

A las edades de 7, 28 y 91 días, desde la fecha de confección del hormigón, se hicieron los ensayos de hormigón endurecido. Éstos consistieron en la determinación de la resistencia a compresión (UNE-EN 12390-3:2003), módulo de elasticidad (UNE 83316:1996), resistencia a tracción indirecta (UNE-EN 12390-6:2001) y penetración de agua bajo presión (UNE-EN 12390-8), pero este último ensayo solamente se realizó a la edad de 91 días.

\subsection{Ensayo de porosimetría por intrusión de mercurio}

Los ensayos de porosimetría por intrusión de mercurio se hicieron con un porosímetro Micromeritics, modelo Autopore IV 9500, que opera hasta una presión de 33.000 psi (228 MPa) y cuyo rango de medida de diámetro de poro es de 0,006 hasta $175 \mu \mathrm{m}$.

Los ensayos se realizaron con muestras a la edad de 91 días, siguiendo la norma ASTM D4404-84 (2004). Esta norma, específica para el análisis de rocas y suelos, es aplicable al hormigón. El peso de las muestras era de 3,5 $\mathrm{g} \pm 0,3 \mathrm{~g}$, y se obtuvieron por cizalladura a fin de evitar fisuración interna.

No hay consenso entre los investigadores respecto a cuáles deben ser las condiciones de preparación de la muestra (17-18). En nuestro caso el tratamiento previo elegido ha consistido en el secado de la misma a una temperatura de $40{ }^{\circ} \mathrm{C}$, hasta peso constante, y en la posterior desgasificación durante 30 minutos con bomba de vacío.

Esta técnica asume como hipótesis que los poros son cilíndricos, por lo que la medida de la porosidad no es real, pero se acepta como aproximación razonable de la estructura porosa en los materiales de base cemento desde 1961, fecha en que fue propuesta por Edel'man (19). Esta técnica permite medir un amplio rango de diámetro de poros, desde los 2,5 nm hasta los $100 \mu \mathrm{m}$.

Washburn (20) propuso un modelo de poro cilíndrico y mediante la ecuación [1] relaciona el tamaño del poro con la presión aplicada en el mercurio. En la ecuación [1] el ángulo de contacto del mercurio con la muestra adoptado ha sido de $130^{\circ}$, tanto en absorción como en desorción. concrete flowability in narrow areas and mould fillability.

\subsection{Hardened concrete}

Seven-, 28- and 91-day specimens were tested for compressive strength (UNE-EN 12390-3:2003), Young's modulus (UNE 83316:1996) and splitting tensile strength (UNE-EN 12390-6:2001) and the 91-day specimens for depth of penetration of water under pressure (UNE-EN 12390-8).

\subsection{Mercury intrusion porosimetry}

The mercury intrusion porosimetry tests were conducted on a Micromeritics Autopore IV 9500 porosimeter that can operate at pressures of up to 33000 psi (228 MPa) over a pore diameter range of 0.006 to $175 \mu \mathrm{m}$.

These tests were conducted on 91-day specimens to ASTM standard D4404-84 (2004) which, while specifically intended for rocks and soil, is applicable to concrete. The $3.5 \mathrm{~g} \pm 0.3 \mathrm{~g}$ samples were obtained by shear to prevent internal cracking.

Researchers have not reached a consensus on the optimal conditions for preparing samples (17-18). In the present study, the preliminary treatment chosen consisted of drying samples at $40{ }^{\circ} \mathrm{C}$ to a constant weight and subsequent degassing for 30 minutes with a vacuum pump.

Since the assumption underlying this technique is that pores are cylindrical, the porosity measure is not real, but accepted as a reasonable estimate of pore structure in cement-based materials since 1961, when it was first proposed by Edel'man (19). This technique can be used to measure a wide range of pore diameters, from $2.5 \mathrm{~nm}$ to $100 \mu \mathrm{m}$.

Washburn (20) proposed a cylindrical pore model and related pore size to the pressure applied to the mercury by means of equation 1. In the equation [1], the contact angle between the mercury and the sample was defined to be $130^{\circ}$ for both absorption and desorption.

$$
p=\frac{-4 \gamma \cos \theta}{d}
$$


Donde:

p presión $\left(\mathrm{N} / \mathrm{nm}^{2}\right)$

$\gamma$ tensión superficial $(\mathrm{N} / \mathrm{nm})$

$\theta$ ángulo de contacto

d diámetro de poro (nm)

Los parámetros fundamentales que se obtienen del ensayo de porosimetría por intrusión de mercurio son tres: la porosidad total, el diámetro de poro promedio y la distribución de la estructura porosa. La porosidad total es el volumen total de poros respecto al volumen total del material, ecuación [2], donde sólo se consideran los poros que están conectados.
Where:

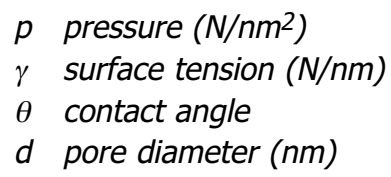

The three essential parameters obtained in the mercury intrusion porosimetry test are: total porosity, mean pore diameter and distribution of the pore structure. Total porosity is the total volume of connected pores with respect to the total volume of the material, equation [2].
Donde:

$\mathrm{p}_{\mathrm{t}}$ porosidad total $(\%)$

$V_{p}$ volumen de poros $\left(\mathrm{mm}^{3}\right)$

$\mathrm{V}_{\mathrm{m}}$ volumen de material $\left(\mathrm{mm}^{3}\right)$

El diámetro de poro promedio es el diámetro correspondiente a asumir una distribución cilíndrica equivalente y está relacionado con la conectividad de los poros. Su cálculo se realiza con la ecuación [3].

$$
p_{t}=\frac{V_{p}}{V_{m}} \times 100
$$

Where:

$p_{t}$ total porosity (\%)

$V_{p}$ pore volume $\left(\mathrm{mm}^{3}\right)$

$V_{m}$ volume of material $\left(\mathrm{mm}^{3}\right)$

The mean pore diameter is the diameter found by assuming an equivalent cylindrical distribution and is related to pore connectivity. It is calculated as shown in equation [3].

$$
\delta=\frac{4 \cdot V}{A}
$$

Donde:

$\delta$ diámetro de poro promedio $(\mathrm{mm})$

$\checkmark$ volumen de poros $\left(\mathrm{mm}^{3}\right)$

A superficie de material $\left(\mathrm{mm}^{2}\right)$

La distribución porosa se estudia mediante el volumen de macroporos y mesoporos. Además, existen otros valores de caracterización microestructural como el diámetro medio de poro, el diámetro medio de la distribución de diámetros de poros, el diámetro crítico o el diámetro umbral, cuyos significados y procedimientos de cálculo se encuentran en la bibliografía (21). En este trabajo se ha elegido el diámetro de poro promedio porque ser el más usado en la bibliografía.
Where:

$\delta$ mean pore diameter ( $\mathrm{mm}$ )

$\mathrm{V}$ pore volume $\left(\mathrm{mm}^{3}\right)$

A area of material $\left(\mathrm{mm}^{2}\right)$

Pore distribution is studied in terms of macro- and mesopore volume. Other parameters for analyzing microstructure may be computed, such as the mean pore diameter, the mean diameter in the distribution of pore diameters and critical or threshold diameters, whose meanings and calculation procedures can be found in the literature (21). Mean pore diameter, the parameter most commonly used in the literature, was adopted in this study. 


\section{RESULTADOS}

\subsection{Resultados de los ensayos de hormigón en estado fresco}

La Tabla 2 muestra un resumen de los valores obtenidos en los ensayos de caracterización del HAC en estado fresco (extensión de flujo, embudo $\mathrm{V}$ y caja en $\mathrm{L}$ ) para cada uno de los hormigones estudiados.

\section{RESULTS}

\subsection{Fresh concrete}

Table 2 summarizes the fresh state experimental findings (slump flow, L-box and V-funnel tests) for the concretes studied.

Tabla 2/ Table 2

Resultados de los ensayos de hormigón fresco.

Experimental characterization of fresh concrete.

\begin{tabular}{|c|c|c|c|c|c|c|c|c|c|c|}
\hline \multicolumn{2}{|c|}{ Hormigón/Concrete } & 1 & 2 & 3 & 4 & 5 & 6 & 7 & 8 & 9 \\
\hline \multirow{2}{*}{$\begin{array}{c}\text { Extensión de flujo I } \\
\text { Slump flow }\end{array}$} & $T_{500}(s)$ & 2.5 & 4 & 3 & 3 & 4.8 & 1.2 & 2 & 3 & 7 \\
\hline & $\varnothing_{m}(\mathrm{~cm})$ & 75 & 70.5 & 69.3 & 65 & 70 & 70 & 65.5 & 63 & 64 \\
\hline Embudo V / V-funnel & $T_{V}(s)$ & 9 & 6 & 9 & 14 & 12 & 5.5 & 8.5 & 10 & 13 \\
\hline \multirow{2}{*}{ Caja en L / L-box } & $T_{600}(s)$ & 5.8 & 3 & 6 & 3 & 3 & 1.4 & 2 & 3 & 4 \\
\hline & $\mathrm{H}_{2} / \mathrm{H}_{1}$ & 0.75 & 0.80 & 0.71 & 0.63 & 0.76 & 0.80 & 0.60 & 0.74 & 0.80 \\
\hline
\end{tabular}

\subsection{Resultados de los ensayos del hormigón endurecido}

Las Figuras 1, 2 y 3 muestran los resultados de resistencia a compresión, módulo de elasticidad y resistencia a tracción indirecta (ensayo de brasileño) para cada hormigón. Los valores presentados corresponden al valor medio de 3 probetas ensayadas. En el caso del hormigón 9 solamente se realizaron ensayos de compresión, módulo de elasticidad y ensayo de tracción indirecta a 28 días y ensayo de compresión a 7 días.

Como se muestra en la Figura 1, el valor de la resistencia a compresión, a 28 días, varía aproximadamente entre 25 y $50 \mathrm{MPa}$.

\subsection{Hardened concrete}

Figures 1, 2 and 3 show the compressive strength, Young's modulus and splitting tensile strength (also known as the Brazilian test) results for each concrete. The values shown represent the mean for three specimens. For concrete 9, the 28-day specimens were tested for compression strength, Young's modulus and indirect tensile strength tests only, and the 7-day specimens for compressive strength only.

As Figure 1 shows, the 28-day compressive strength ranged from approximately 25 to $50 \mathrm{MPa}$.

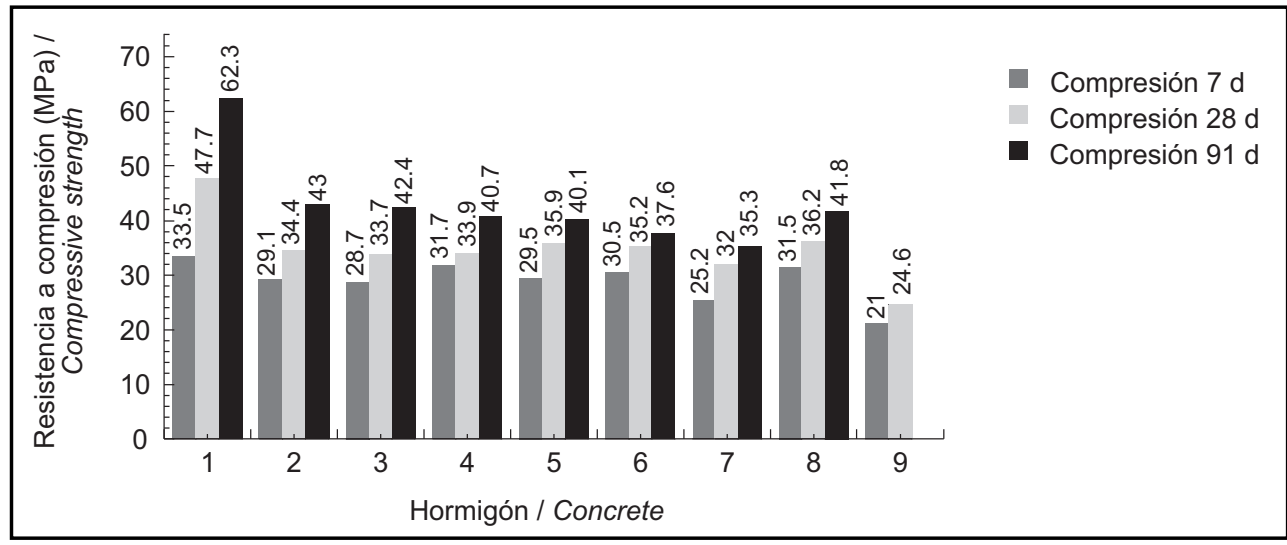

Figura 1. Resistencia a compresión.

Figure 1. Compressive strength.

En la Figura 2, se aprecia que el valor del módulo de elasticidad, a 28 días, se sitúa, aproximadamente, entre 23 y $36 \mathrm{GPa}$, dependiendo del tipo de hormigón.
According to the results in Figure 2, the 28-day Young's modulus fluctuated from 23 to $36 \mathrm{GPa}$, depending on the type of concrete. 


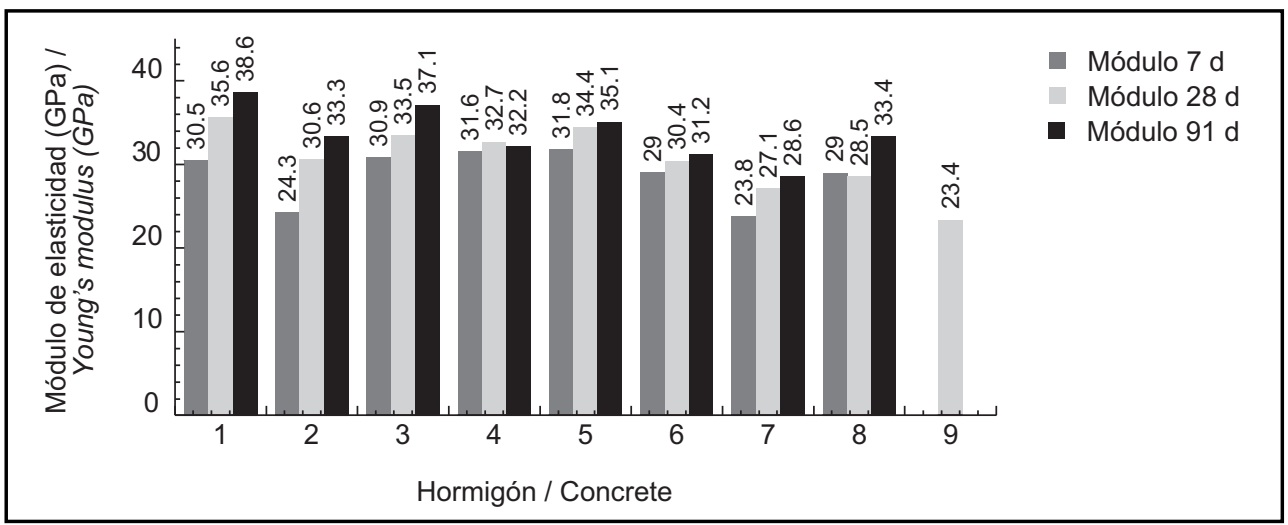

Figura 2. Módulo de elasticidad.

Figure 2. Young's modulus.

La Figura 3 muestra que el valor del ensayo de tracción indirecta, a 28 días, presenta menor dispersión que los anteriores ensayos situándose, aproximadamente, entre 3 y 4,5 MPa.
Figure 3 shows that the 28-day indirect tensile strength values were less scattered than the other two parameters, ranging from around 3 to $4.5 \mathrm{MPa}$.

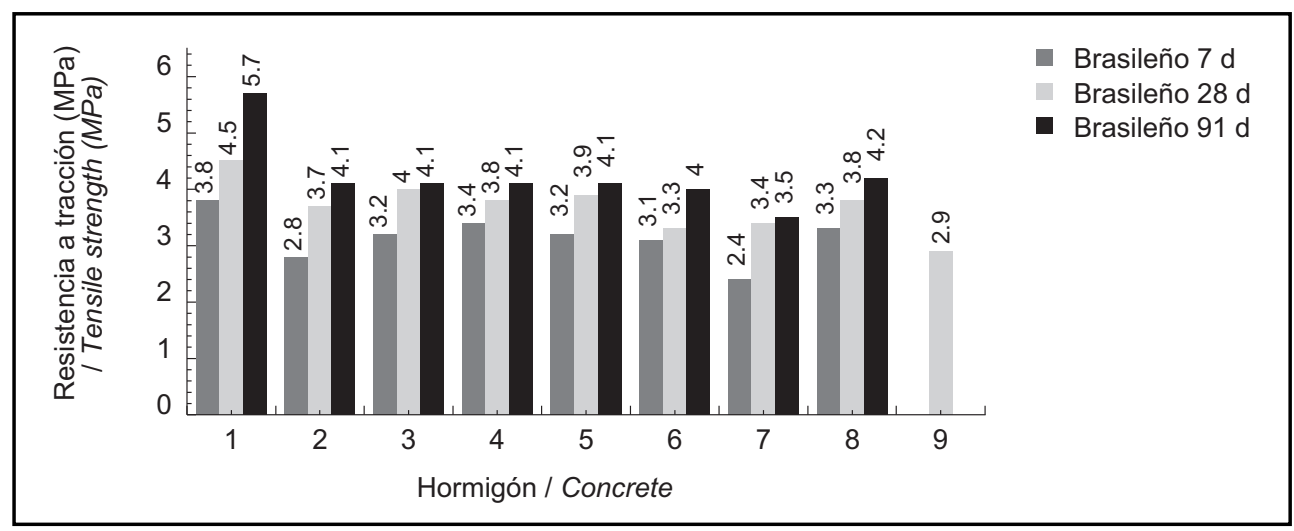

Figura 3. Resistencia a tracción indirecta. Figure 3. Splitting tensile strength.

\subsection{Resultados de los ensayos de permeabilidad al agua y porosimetría por intrusión de mercurio}

La Figura 4 muestra la profundidad máxima de penetración de agua y la resistencia a compresión a los 91 días

\subsection{Water penetration under pressure and mercury intrusion porosimetry}

Figure 4 shows the maximum depth of water penetration and compressive strength in 91-day

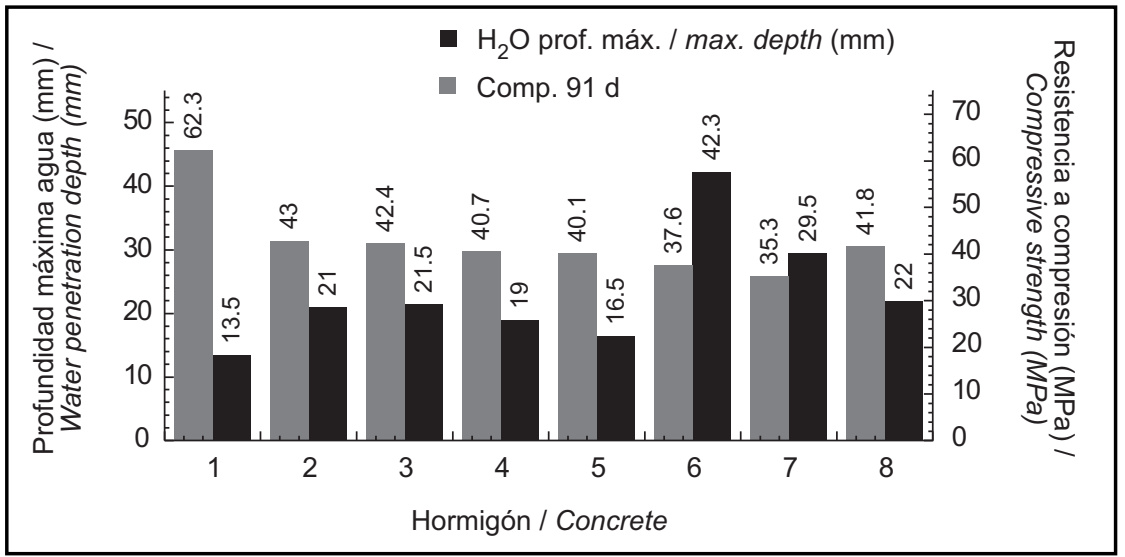

Figura 4. Penetración de agua bajo presión y resistencia a compresión a los 91 días.

Figure 4. Penetration depth of water under pressure and compressive strength in 91-day specimens. 
de edad. Los valores corresponden al valor medio de 3 probetas ensayadas.

La Figura 5 presenta los resultados de diámetro de poro promedio $(\mathrm{nm})$ y la profundidad máxima de penetración de agua $(\mathrm{mm})$ para cada uno de los hormigones estudiados. Los valores corresponden al valor medio de 3 probetas ensayadas. samples. The values shown represent the mean for three specimens.

The mean pore diameter $(\mathrm{nm})$ results are shown in Figure 5, along with the maximum depth of water penetration $(\mathrm{mm})$ for all the concretes studied. The values shown represent the mean for three specimens.

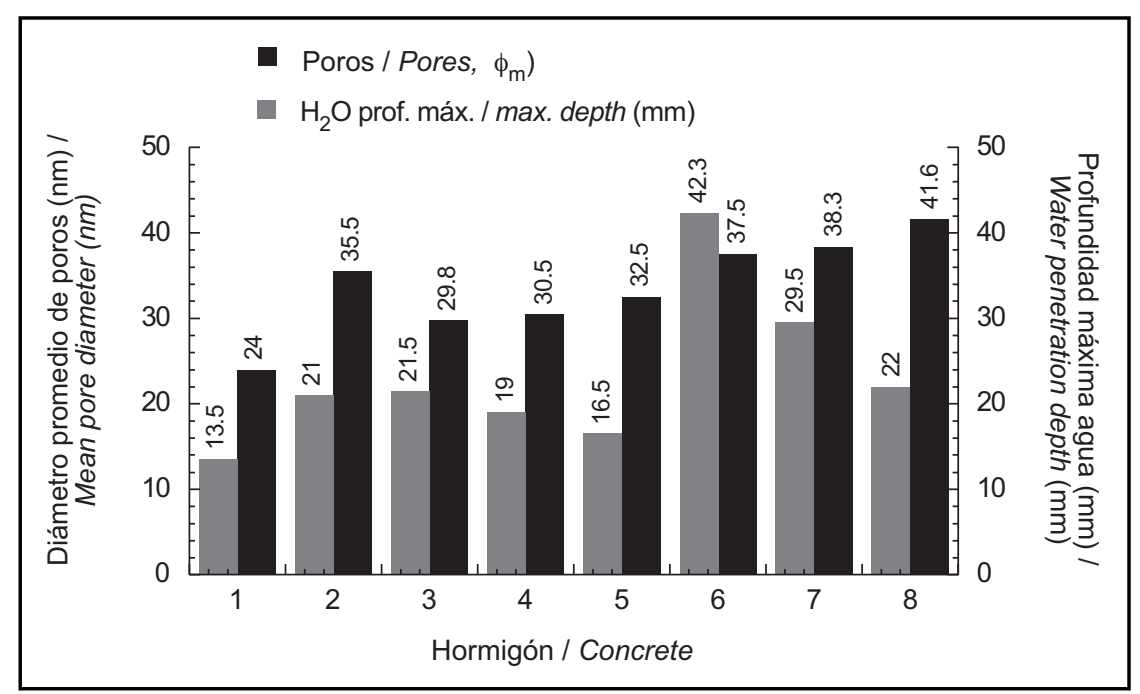

Figura 5. Diámetro de poro promedio y penetración de agua bajo presión. Figure 5. Mean pore diameter and penetration depth of water under pressure.

En la Figura 6 se puede observar el porcentaje de porosidad total y la resistencia a compresión a los 91 días de edad.
Total porosity and compressive strength in 91-day specimens are shown in Figure 6.

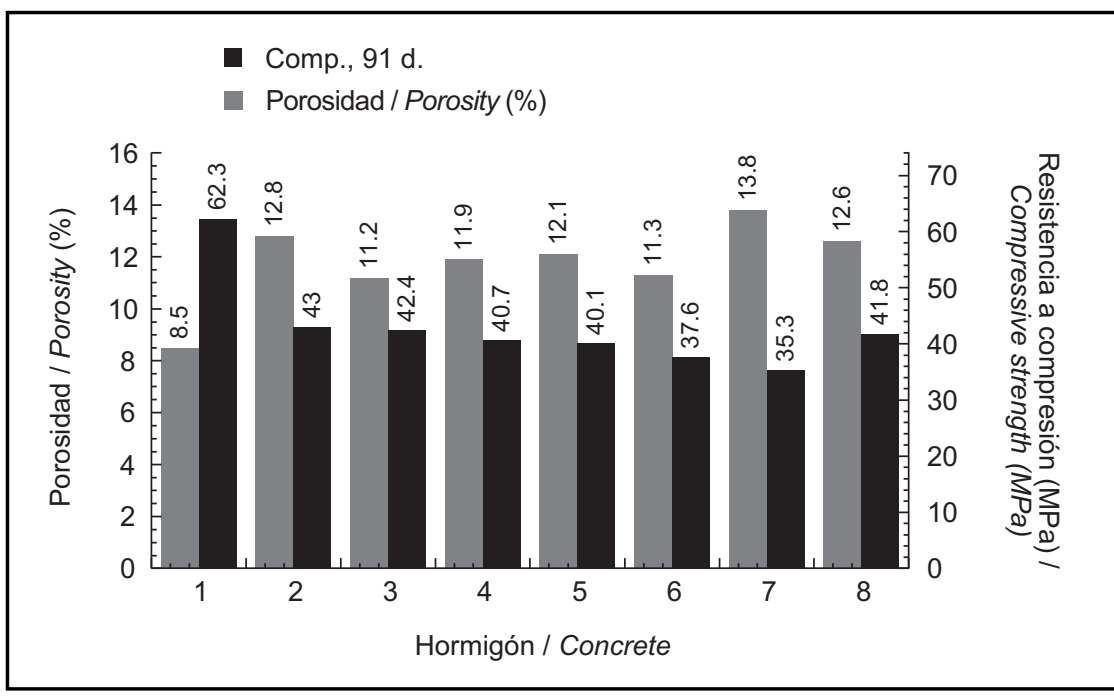

Figura 6. Porosidad total y resistencia a compresión a los 91 días. Figure 6. 91-day total porosity and compressive strength.

La Figura 7 muestra la distribución de poros en los hormigones estudiados.
Figure 7 shows the pore distribution in the concretes studied. 


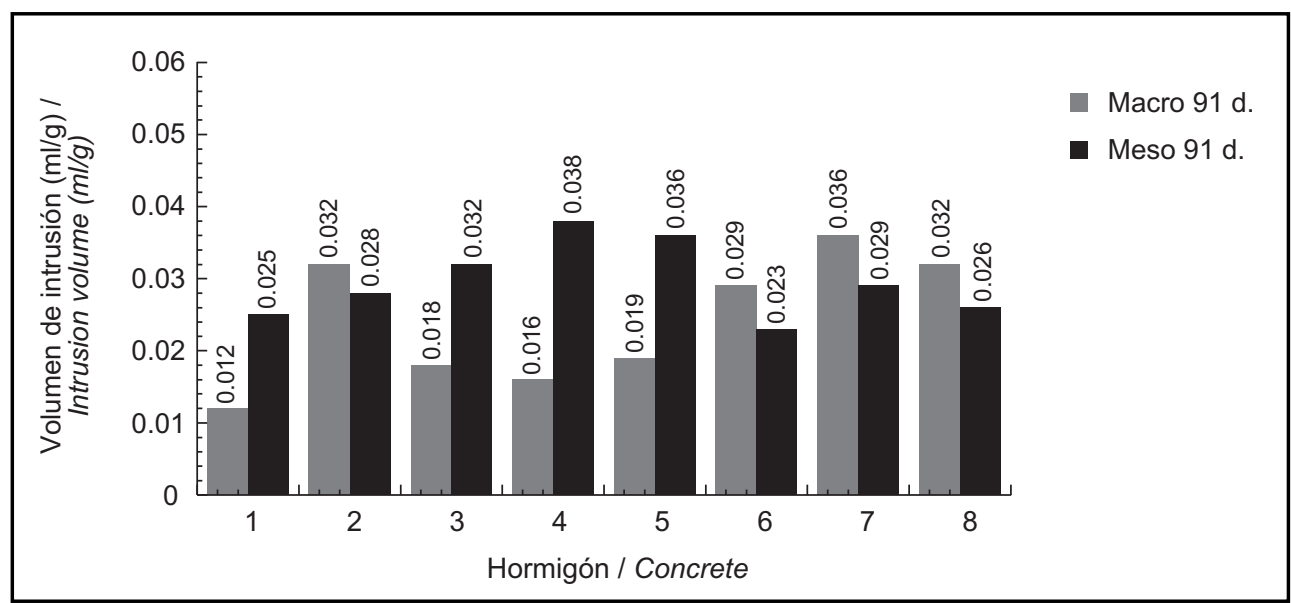

Figura 7. Distribución de poros por intrusión de mercurio a los 91 días de edad. Figure 7. 91-day pore size distribution (MIP).

Estos ensayos no se han realizado con el hormigón 9 (CEM II/B-L 32,5N) debido a que, a 28 días de edad, no se alcanza la resistencia solicitada.

\section{DISCUSIÓN}

En la Tabla 2 se puede observar que cuatro de los hormigones ensayados poseen un coeficiente de bloqueo en la caja en $L$ por debajo del límite de 0,75 que se establece en el Anejo 17 de la EHE-08 (16), aunque dos de ellos tienen valores muy próximos a 0,75 . No obstante algunos autores como Gettu et al. (6) indican que hormigones con coeficientes más bajos, hasta 0,60 , han mostrado resultados aceptables en aplicaciones estructurales (15).

Se ha intentado ajustar las dosificaciones a un contenido máximo de cemento de $350 \mathrm{~kg} / \mathrm{m}^{3}$ de hormigón. En algunos casos, se ha podido reducir esa cantidad a 325 $\mathrm{kg} / \mathrm{m}^{3}$ como es el caso de los hormigones 3 y 5, o a 300 $\mathrm{kg} / \mathrm{m}^{3}$ para el hormigón 2. Conviene señalar que en el caso del hormigón 7, la cantidad de cemento se ha aumentado a $375 \mathrm{~kg} / \mathrm{m}^{3}$ al no alcanzarse la resistencia prevista de $30 \mathrm{MPa}$ con $350 \mathrm{~kg} / \mathrm{m}^{3}$. Además, hay que señalar que la cantidad de cemento en el hormigón 9 debería de ser mayor de $350 \mathrm{~kg} / \mathrm{m}^{3}$ para obtener la resistencia a compresión prevista, debido a que es el único hormigón cuyo cemento empleado es de clase resistente 32,5 . Pero no se ha aumentado porque uno de los criterios de diseño es obtener HACs económicos. En el caso del hormigón 1 el contenido de cemento ha sido de $280 \mathrm{~kg} / \mathrm{m}^{3}$ de hormigón.

La relación agua/cemento ha sido 0,55, a excepción de los tres primeros hormigones en los que se ha reducido a 0,50. La cantidad de áridos (grava y arena) ha sido la misma para todos los hormigones.
These tests were not run on concrete 9 (CEM II/B-L $32.5 \mathrm{~N}$ ) because it failed to reach the required 28-day strength.

\section{DISCUSSION}

Table 2 shows that while four of the concretes tested had L-box blocking ratios lower than the 0.75 minimum laid down in Annex 17 to the Spanish structural concrete code, EHE-08 (16), in two cases the values were close to that figure. Moreover, some authors, such as Gettu et al. (6), for instance, report that concretes with ratios as low as 0.60 have performed acceptably in structural applications (15).

Attempts were made to adjust proportioning to a maximum cement content of $350 \mathrm{~kg} / \mathrm{m}^{3}$ of concrete. In some cases, this amount could be lowered to $325 \mathrm{~kg} / \mathrm{m}^{3}$, such as in concretes 3 and 5 , to $300 \mathrm{~kg} / \mathrm{m}^{3}$ in concrete 2 or even to $280 \mathrm{~kg} / \mathrm{m}^{3}$ in concrete 1 . In concrete 7, however, the amount of cement was increased to 375 $\mathrm{kg} / \mathrm{m}^{3}$ because the predefined strength, $30 \mathrm{MPa}$, was not attained with $350 \mathrm{~kg} / \mathrm{m}^{3}$. In concrete 9 also, more than $350 \mathrm{~kg} / \mathrm{m}^{3}$ cement would have been needed to reach the minimum compressive strength established, because it was the only concrete made with strength class 32.5. The proportion was not raised, however, because one of the design criteria was to prepare cost-effective SCCs.

The water/cement ratio was 0.55 except in the first three concretes, where it was lowered to 0.50. The same amount of aggregate (gravel and sand) was used in all the concretes studied. 
No se han empleado aditivos modificadores de viscosidad por razones de economía. No obstante, no hay incoveniente en emplearlos cuando sean totalmente necesarios.

Se ha observado que un contenido de superplastificante superior al $2 \%$ del peso de cemento provoca una pérdida de fluidez rápida en el hormigón por lo que se ha intentado reducir su cantidad aproximadamente al 1,5\%, aunque en algunos casos se ha tenido que llegar al 2, o incluso el 2,2\%. Conviene destacar que se ha trabajado con un solo tipo de aditivo superplastificante, y que muy probablemente sea conveniente realizar pruebas complementarias que permitan adoptar el tipo de aditivo más idóneo para cada cemento.

Como era de esperar, el uso de ceniza volante como filler, debido a su carácter puzolánico, mejora las resistencias mecánicas, en comparación con el uso de filler calizo. Esta mejora se ha apreciado incluso en la resistencia a 28 días.

Con el cemento blanco estudiado se alcanza una resistencia a compresión a 28 días ligeramente superior a 30 $\mathrm{MPa}$, mientras que con los otros cementos esta diferencia de resistencia es superior. Esto puede deberse a que aparte del filler calizo utilizado como adición, el propio cemento ya incorpora hasta, aproximadamente, un 25\% de la misma al tratarse de un cemento blanco.

Análogo razonamiento se hace para el cemento CEM II/B-L 32,5 N, que da hormigones que apenas llegan a los $25 \mathrm{MPa}$ de resistencia a compresión a los 28 días, lo que se justifica dado que tiene un $40 \%$ de adición caliza. Aunque se han empleado $350 \mathrm{~kg} / \mathrm{m}^{3}$ de cemento, el aumento de la cantidad del mismo no ha mejorado la resistencia de forma significativa por lo que no parece viable obtener una resistencia media de $30 \mathrm{MPa}$. Probablemente con este cemento habría que emplear más de $400 \mathrm{~kg} / \mathrm{m}^{3}$ o usar adiciones activas como las cenizas volantes.

Con respecto a los otros hormigones en resistencia a compresión, en los hormigones 2, 3 y 8 se aprecia un aumento de la resistencia a 91 días debido a la adición puzolánica que llevan incorporada los cementos que se emplean en esos hormigones, ceniza volante para los hormigones 2 y 3 , y puzolana para el hormigón 8 . Y, respecto al hormigón 6 se obtiene un valor de resistencia bajo que, como se explicará posteriormente, puede ser debido a su microestructura.

Análoga discusión se hace para la resistencia a tracción indirecta a 28 días debida a que está muy relacionada con la resistencia a compresión. Conviene destacar que a 91 días no existe tanta dispersión de resultados como
Admixtures that modify viscosity were not used for reasons of cost, although they could be included if absolutely necessary.

Since a superplasticizer content of over 2\% (cement wt) was found to prompt an abrupt loss of concrete flowability, the dose was reduced to approximately $1.5 \%$ wherever possible. Nonetheless, 2 or even $2.2 \%$ was required in some cases. While only one type of superplasticizer was used here, supplementary tests to determine the most suitable admixture for each type of cement would be advisable.

As expected, the use of fly ash instead of limestone as a filler yielded concretes with greater mechanical strength due to the pozzolanicity of the ash. This rise in strength was observed even in the 28-day specimens.

The 28-day compressive strength obtained with the white cement studied was slightly higher than $30 \mathrm{MPa}$, while the values obtained for the other cements were even higher. The explanation may be that in white cement, in addition to the filler, the cement itself contained approximately $25 \%$ limestone (for whitening).

A similar explanation can be given for the behaviour of cement CEM II/B-L $32.5 \mathrm{~N}$, which yielded concretes whose 28-day compressive strength barely reached 25 $\mathrm{MPa}$, attributable to their $40 \%$ limestone content. Inasmuch as strength did not rise significantly even when $350 \mathrm{~kg} / \mathrm{m}^{3}$ of cement were used, obtaining a mean strength of $30 \mathrm{MPa}$ did not appear to be feasible. This cement would probably call for over $400 \mathrm{~kg} / \mathrm{m}^{3}$ or the inclusion of active additions such as fly ash to attain the desired strength.

Concretes 2, 3 and 8 showed higher 91-day compressive strength than the others due to the pozzolanic addition in the cements used: fly ash in concretes 2 and 3 and pozzolan in concrete 8 . The low strength value obtained for concrete 6 may have been due to its microstructure, as explained below.

The 28-day splitting tensile strength followed a similar pattern, for this parameter is closely related to compressive strength. Nonetheless, the 91-day values exhibited less dispersion than the 
ocurría en el caso de la resistencia a compresión a excepción, de los hormigones 1 y 7.

El módulo de elasticidad muestra un comportamiento análogo al de la resistencia a compresión. Los estudiados por algunos autores (4) muestran que también en el HAC se puede establecer una correspondencia entre el módulo de elasticidad y la raíz cuadrada de la resistencia a compresión característica, si bien en el caso de los HAC de baja resistencia esta relación es menor.

Respecto a la durabilidad, el hormigón 1 , que contiene $280 \mathrm{~kg}$ de cemento I 42,5 R/SR y una relación a/c de 0,50 , es el que presenta menor porosidad y permeabilidad al agua, y mayor resistencia a compresión (ensayos a los 91 días). En términos generales, los resultados obtenidos muestran un hormigón resistente, poco poroso e impermeable. No sólo presenta una porosidad total pequeña, sino que también el tamaño de poros es sensiblemente más reducido. Estos resultados corroboran que la adición de cenizas volantes crea centros de nucleación en los poros que aumenta la compacidad de la matriz y con ello se dificulta la penetración del agua y de los agentes agresivos.

El resto de los hormigones, con adición de filler calizo, muestran diferencias significativas, tanto en resistencia a compresión como en permeabilidad, con respecto al hormigón con adición de cenizas volantes.

En todos los hormigones con adición de filler calizo se ha obtenido una porosidad parecida, situándose en un rango de $11,2 \%$ a $13,8 \%$. Sin embargo existe una mayor dispersión en cuanto a su diámetro de poro promedio que se sitúa entre 30 y 42 nm, siendo el hormigón 8 el que mayor diámetro de poro promedio presenta. Asimismo, entre ellos también existen diferencias importantes en cuanto a la profundidad de penetración de agua bajo presión, lo que muestra que el radio de poro promedio es un parámetro que influye en la misma, aunque no el único. El valor de la porosidad total (no tanto) y el porcentaje de macroporosidad pueden ser factores determinantes en este fenómeno.

Del mismo modo, no se observa una relación entre la profundidad de penetración de agua bajo presión y la resistencia a compresión completamente clara. Si bien se aprecia una tendencia general a disminuir dicha resistencia cuando aumenta la profundidad de penetración. Este efecto, lógico, por otra parte, se presenta igualmente en los hormigones tradicionales. Los dos valores mayores de profundidad de penetración de agua los presentan los hormigones 6 y 7, que han obtenido menores valores de resistencia. El resto de ellos presentan resistencias similares entorno a los $40 \mathrm{MPa}$ que no difieren en ningún caso en más del $10 \%$. Sin embargo, los valores de profundidad compressive strength findings, except in concretes 1 and 7.

Young's modulus also varied along lines similar to compressive strength. In the SCCs studied by some authors (4), a correlation could be established between Young's modulus and the square root of characteristic compressive strength, although the relationship was looser for low strength SCCS.

Of all the 91-day materials, concrete 1, which contained $280 \mathrm{~kg}$ of cement I $42.5 \mathrm{R} / \mathrm{SR}$ and a $\mathrm{w} / \mathrm{c}$ ratio of 0.50 , had the lowest porosity and water permeability, as well as the highest compressive strength. In other words, it scored highest in terms of durability of all the concretes tested. Moreover, the effect of its low total porosity was enhanced by its very small pore size. These results confirmed that the nucleation sites induced in the concrete pores by the fly ash added to the cement generated a more compact matrix, hindering the inflow of water and aggressive agents.

Both the compressive and permeability findings for the rest of the concretes, in which limestone filler was the addition, differed significantly from the results for fly ash-containing concrete 1.

Porosity was found to be very similar in all the concretes with a limestone filler, ranging from 11.2 to $13.8 \%$. Greater dispersion was observed in mean pore diameter, however, which fluctuated from 30 to $42 \mathrm{~nm}$. The largest mean diameter was found in concrete 8. Substantial differences were also observed in the penetration depth of water under pressure, an indication that mean pore radius is one but not the only determinant in this parameter. Others may be total porosity (to a lesser extent) and the percentage of macro-pores.

Similarly, no clear relationship was observed between penetration depth of water under pressure and compressive strength, although strength tended to decline with increasing depth. This logical effect is also present in traditional concrete. The two deepest water penetration values were observed in concretes 6 and 7, which also exhibited the lowest strength. All the other concretes had strength values on the order of $40 \mathrm{MPa}$, with differences of $10 \%$ or less among them. Nonetheless, the penetration depths of water 
de penetración de agua muestran valores claramente diferentes, que en algunos casos alcanzan diferencias del $80 \%$.

Los valores de profundidad de penetración de agua y resistencia a compresión se interpretan mejor si se comparan con la distribución porosa de los hormigones, en concreto, con el volumen de macroporos ya que éstos afectan a dichos valores. Como se observa los hormigones $2,6,7$ y 8 son los que presentan valores elevados de macroporosidad, que a su vez coincide en que también tienen un mayor diámetro de poro promedio y una elevada porosidad en comparación con el resto de los hormigones.

Los hormigones 6 y 7 tienen una resistencia a compresión más baja en comparación con el resto y puede deberse a su elevado volumen de macroporos; en cambio los valores de la resistencia a compresión de los hormigones 2 y 8 no se ve tan afectada por los mismos, lo que parece indicar que el porcentaje de adiciones activas de estos hormigones tiene una influencia significativa en este parámetro.

Al igual que ocurre con la resistencia a compresión, los hormigones 6 y 7 son los que presentan una máxima de penetración de agua en comparación con el resto de los hormigones. Sin embargo, los hormigones 2 y 8 tienen una penetración máxima de agua similar a la del resto de los hormigones. Esto podría deberse a que exista una mayor conexión entre los macroporos en el caso de los hormigones 6 y 7 . En el caso de los hormigones 2 y 8 , aunque presentan una elevada macroporosidad, sus propiedades mecánicas y comportamiento frente a penetración de agua no se ven significativamente afectadas por su distribución porosa lo que podría indicar que la conexión entre sus poros es menor.

Los resultados obtenidos indican claramente que si bien todos los parámetros estudiados están relacionados y existe una clara conexión en los valores extremos, pequeñas variaciones de los mismos no afectan del mismo modos a todos ellos.

\section{CONCLUSIONES}

De los resultados obtenidos se pueden extraer las siguientes conclusiones:

- Aunque se ha empleado un solo tipo de aditivo superplastificante, conviene realizar pruebas para elegir el óptimo para cada cemento empleado.

- Un contenido elevado de aditivo superplastificante, superior al $2 \%$ en peso de cemento, puede resultar perjudicial, produciendo una rápida pérdida de fluidez en el hormigón, e incluso la segregación. under pressure differed clearly, with a spread of up to $80 \%$.

Penetration depth and compressive strength values can be better interpreted if they are compared to the pore distribution in concrete, and more specifically the volume of macro-pores, which affect these values. Concretes 2, 6, 7 and 8 exhibited higher macroporosity, a larger mean pore diameter and higher total porosity than the other concretes.

The low compressive strengths observed in concretes 6 and 7 may have been due to their macro-pore volume. Yet in concretes 2 and 8, compressive strength was unaffected by macroporosity, indicating that the percentage of active additions in these concretes had a significant impact on strength.

While high macroporosity, low compressive strength concretes 6 and 7 had the highest water penetration values of all the materials studied, concretes 2 and 8, with a similar volume of macro-pores, exhibited penetration values in line with the remaining concretes. These differences may be due to greater macro-pore connectivity in concretes 6 and 7 and lower inter-pore connectivity in concretes 2 and 8.

These findings clearly showed that while the parameters studied are inter-related, in particular as regards the extreme values, minor variations did not affect them all in the same measure.

\section{CONCLUSIONS}

The following conclusions can be drawn from the research findings discussed above:

- While only one type of superplasticizer was used, tests should be conducted to choose the optimal compound for each type of cement.

- A high superplasticizer content, i.e., over $2 \%$ may be detrimental, causing a rapid decline in flowability or even segregation. 
- Con los cementos con adición de filler calizo es más difícil conseguir resistencias medias (30 MPa), sin sobrepasar los $350 \mathrm{~kg} / \mathrm{m}^{3}$ de cemento, respecto a otros cementos que no poseen esta adición complementaria.

- Cuando se utiliza como adición al hormigón cenizas volantes se obtiene una mejora en las características mecánicas, disminución de la porosidad y de la profundidad de penetración del agua, con respecto al empleo de adición de filler calizo, es decir, el uso de las cenizas volantes como adición mejora las propiedades mecánicas y disminuye la permeabilidad de los hormigones autocompactantes, lo que coincide con lo observado en los hormigones convencionales.

- De los resultados del ensayo de penetración de agua bajo presión se desprende que existe una tendencia generalizada a que la resistencia a compresión sea tanto menor cuanto mayor sea la profundidad de ésta. Para hormigones de resistencias a compresión similares el volumen de macroporos determina el comportamiento frente a gradientes hidráulicos.

- El valor de la porosidad total no presenta una gran dispersión en los hormigones con filler calizo, sin embargo la distribución porosa sí que presenta diferencias importantes.

- El parámetro de porosidad por sí solo no permite diferenciar comportamiento a excepción de que existan diferencias significativas como en el caso del hormigón 1. Sin embargo, el diámetro de poro promedio y la distribución porosa son más significativas respecto al comportamiento de mecanismos de transporte.

- El hormigón fabricado con un cemento tipo CEM II/A$\mathrm{S} 42,5 \mathrm{~N}$ posee una porosidad similar a la de los fabricados con los otros tipos de cementos de igual resistencia, pero con un radio promedio de poro mayor que el que presentan estos, de aquí su mayor profundidad de penetración de agua. Este hecho puede justificarse por la forma irregular de las escorias, lo que provoca un peor sellado de los poros.

Todo ello pone de manifiesto que el comportamiento frente a la penetración al agua a presión de los hormigones autocompactantes está determinado no sólo por la dosificación del hormigón, que afecta a las propiedades reológicas y mecánicas, sino también por el porcentaje de macroporos y a su distribución.

\section{AGRADECIMIENTOS}

Los autores desean agradecer al Instituto Español del Cemento y sus Aplicaciones (IECA) la financiación parcial de los ensayos realizados. Además agradecen al Ministerio de Educación la concesión del proyecto BIA200803523, y al Ministerio de Fomento el proyecto MFOM 01/2007.
- Medium strength (30 MPa) is more difficult to attain in cements containing a limestone filler with cement dosages of $350 \mathrm{~kg} / \mathrm{m}^{3}$ or less than in other cements without this addition.

- When fly ash instead of a limestone filler is used, mechanical properties can be improved and porosity and penetration depth of water reduced. In other words, the use of fly ash as an addition enhances mechanical properties and reduces permeability in self-compacting concrete, just as it does in conventional concretes.

- Compressive strength generally tended to decline where the penetration depth of water under pressure was deepest. In concretes with similar compressive strengths, differences in hydraulic gradients were determined by the volume of macro-pores.

- While total porosity values were not widely dispersed in concretes with limestone fillers, their pore size distribution findings did differ substantially.

- Porosity in and of itself did not suffice to differentiate behaviour, except where the differences were significant, such as in concrete 1. By contrast, mean pore diameter and pore size distribution had a greater effect on transport mechanisms.

- While concrete porosity was observed to be similar whether made with CEM II/A-S $42.5 \mathrm{~N}$ or other types of same-strength cements, the mean pore radius was larger in the former, which would explain the greater depth of water penetration. The explanation may lie in the irregular shape of slag, which would seal the concrete pores less effectively.

All the foregoing shows that the penetration depth of water under pressure in self-compacting concrete is determined not only by concrete dosage, which affects rheological and mechanical properties, but also by the percentage and distribution of macro-pores.

\section{ACKNOWLEDGEMENTS}

The tests conducted in this study were partially funded by the Instituto Español del Cemento y sus Aplicaciones (Spanish institute of cement and cement applications, IECA). Funding was also received from the Spanish Ministerio de Educación under project BIA2008-03523, and the Ministerio de Fomento, under project MFOM 01/2007. 


\section{BIBLIOGRAFÍA / BIBLIOGRAPHY}

(1) Okamura, H.: "Self Compacting High-Performance Concrete", Concr. Int., vol. 19, no 7 (1997), pp. 50-54.

(2) EFCA, EFNARC: The European Guidelines for Self-Compacting Concrete. Mayo 2005.

(3)ACI 237R-07: Self-Consolidating Concrete, April 2007.

(4) De Schutter, G.; Bartos; P. J.; Domone, P.; Gibbs, J.: "Self-Compacting Concrete", CRC Press, 296 pp., 2008.

(5) Gettu, R.; Agulló, L.: "Estado del arte del hormigón autocompactable y su caracterización (Parte I)", Cemento y Hormigón, no 861 (2004), pp. 50-67.

(6) Gettu, R.; Agulló, L.: "Estado del arte del hormigón autocompactable y su caracterización (Parte II)", Cemento y Hormigón, nº 862 (2004), pp. 32-55.

(7) Assié, S.; Escadeillas, G.; Waller, V.: "Estimates of self-compacting concrete 'potential' durability", Construction and Building Materials, no 21 (2007), pp. 1909-1917. doi:10.1016/j.conbuildmat.2006.06.034

(8) De Schutter, G.; Audenaert, K.: Durability of Self-Compacting Concrete. State of the Art Report of RILEM Technical Committee 205DSC, RILEM, France, 2007.

(9) Boel, V.; Audenaert, K.; De Schutter, G.: "Pore distribution of hardened cement paste in self compacting concrete", Seventh CANMET/ACI International Conference on Durability of Concrete, SP-234-11, 2006.

(10) Audenaert, K.; Boel, V.; De Schutter, G.: "Influence of capillary porosity on transport properties of self compacting concrete", Eighth CANMET/ACI International Conference on Recent Advances in Concrete Technology, SP-235-1, 2006.

(11) Zhu, W.; Bartos, P. J. M.: "Permeation properties of self-compacting concrete", Cem. Concr. Res., no 33 (2002), pp. $921-926$.

(12) Aligizaki, K. K.: Pore Structure of Cement-Based Materials, Modern Concrete Technology 12, Taylor \& Francis, 2006.

(13) Ministerio de Fomento. Instrucción para la Recepción de Cementos (RC-08).

(14) Fernández Gómez, F.; Burón Maestro, M.: "Determinación de las características mecánicas de un hormigón autocompactante H-30", Cemento y Hormigón, no 903 (2007), pp. 52-65.

(15) Tviksta, L.: Guidelines, Report of Task 9: End Product, Rational Production and Improved Working Environment through using SelfCompacting Concrete, Brite EuRam project BRPR-CT96-0366, pp. 48.

(16) Ministerio de Fomento. Anejo 17, "Hormigón autocompactante". Instrucción del Hormigón Estructural (EHE-08).

(17) Diamond, S.: "Mercury Porosimetry: an inappropiate method for the measurement of pore size distributions in cement-based materials", Cem. Concr. Res., no 30 (2000), pp. 1517-1525. doi:10.1016/S0008-8846(00)00370-7

(18) Aligizaki, K. K.: Pore structure of cement-based materials. Testing, interpretation and requirements. Abingdon. Taylor \& Francis, 2006.

(19) Edel'man, L. I.; Sominskii, D. S. y Kopchikova, N. V.: "Pore size distribution in cement rocks", Colloid Journal, 23 (2) (1961), pp. 192-196.

(20) Washburn, E. W.: "Note on a method of determining the distribution of pore size in a porous material", Proceedings of the National Academy of Sciences, 7 (4) (1921), pp. 115-116. doi:10.1073/pnas.7.4.115

(21) Segura Pérez, I.: Tesis doctoral Caracterización del proceso de descalcificación en morteros, mediante ensayos destructivos y no destructivos, ETSI de Caminos, Canales y Puertos, Universidad Politécnica de Madrid, Madrid, 2008. 